\title{
Serum Levels of True Insulin, C-Peptide and Proinsulin in Peripheral Blood of Patients with Cirrhosis
}

\author{
T. Kasperska-Czyźykowa ${ }^{1}$, L.G. Heding ${ }^{2}$ and A. Czyżyk ${ }^{1}$ \\ ${ }^{1}$ Department of Gastroenterology and Metabolic Diseases, Medical Academy of Warsaw, Poland, and \\ ${ }^{2}$ Novo Research Institute, Bagsvaerd, Denmark
}

\begin{abstract}
Summary. The levels of proinsulin, immunoreactive insulin, true insulin (calculated from the difference, namely immunoreactive insulin-proinsulin) and $\mathrm{C}$-peptide were determined in the fasting state and during a 3-h oral glucose tolerance test after administration of $100 \mathrm{~g}$ of glucose in 12 patients with cirrhosis with normal oral glucose tolerance test $(50 \mathrm{~g})$ and in 12 healthy subjects serving as controls. In the patients with cirrhosis the serum levels of proinsulin and immunoreactive insulin were significantly higher in the fasting state and after glucose loading than in the healthy subjects. The serum level of true insulin was also higher in the patients with cirrhosis,
\end{abstract}

but the difference was less pronounced and only significant at a few of the time points. The serum level of C-peptide was very similar in both groups. These results emphasize that cirrhosis is a condition in which the serum proinsulin level is raised and that this hyperproinsulinaemia contributes greatly to the increased immunoreactive insulin levels observed in patients with this disease.

Key words: Insulin, cirrhosis, C-peptide, proinsulin, oral glucose tolerance test.
After the introduction of a radioimmunoassay for serum (plasma) insulin determination (IRI) many authors reported raised levels of this hormone in the peripheral blood of patients with cirrhosis $[1,5-7,9,16-19]$. In recent years, new techniques for studying the fate of insulin released from the B cells of pancreatic islets have become available by determination of C-peptide and proinsulin in the peripheral blood.

C-peptide is released in equimolar amounts to insulin from the B cells and, contrary to the latter, it passes nearly completely into the systemic circulation; thus its concentration in the peripheral blood reflects the functional capacity of the B cells more accurately than the IRI level [2]. On the other hand, there is increasing evidence that proinsulin accounts for a large part of IRI. Therefore, when determining the level of true insulin in the serum, proinsulin must be subtracted from the total IRI value. Thus, it has been shown that in certain situations, e.g. in the late stage of an oral glucose tolerance test (GTT), the molar concentration of serum proinsulin may be two to three times higher than that of true insulin [13].

In this investigation, $\mathrm{B}$ cell secretion and the composition of IRI in the blood of patients with cirrhosis were evaluated and compared with that of control subjects.

\section{Patients and Methods}

The investigations were carried out in 12 patients with cirrhosis and 12 healthy subjects. The group of patients comprised eight men and four women (aged 32-60years; mean age 52.2 years) with a body weight index varying from $0.75-1.42$ (mean $0.98 \pm 0.17$ ). All subjects studied were informed about the intended investigations and their aim and consented to participate. In the patients with ascites and/or oedema, the investigation was carried out after complete disappearance or greatest possible reduction of these signs and always at least 3 days after withdrawal of diuretics and when normal serum sodium and potassium levels were established. All patients formed a fairly homogenous group with respect to progression of disease. The clinical data of the patients and control subjects are shown in Table 1. Cirrhosis was decompensated in all cases and the diagnosis was based on the results of physical examination, laboratory investigations (serum protein fractions, bilirubin level, bromsulphalein retention) and radiological examination of the oesophagus. In 11 patients the diagnosis was confirmed by histological examination and was further characterized by a $50 \mathrm{-g}$ oral GTT. In six cases the result of the oral GTT with $50 \mathrm{~g}$ glucose was normal according to the criteria of the EASD, in six cases the blood glucose level at $1 \mathrm{~h}$ was in the borderline range, and in three patients from this subgroup it exceeded the borderline range slightly at $2 \mathrm{~h}$ (Table 1 ).

The control group comprised 10 men and two women (aged $32-59$ years (mean age 48.3 years), and their body weight index ranged from $0.77-1.12$ (mean $0.97 \pm 0.14$ ). None had a family history of diabetes. They had no evidence of hepatobiliary disease, renal dysfunction or endocrine disturbances. 
Table 1. Clinical data of healthy subjects and patients with cirrhosis

\begin{tabular}{|c|c|c|c|c|c|c|c|c|c|c|c|c|c|c|c|c|c|c|}
\hline \multicolumn{7}{|c|}{ Healthy subjects } & \multicolumn{12}{|c|}{ Cirrhotic patients } \\
\hline \multirow[t]{2}{*}{$\begin{array}{l}\text { Patient } \\
\text { No. }\end{array}$} & \multirow[t]{2}{*}{ Sex } & \multirow{2}{*}{$\begin{array}{l}\text { Age } \\
\text { (years) }\end{array}$} & \multirow{2}{*}{$\begin{array}{l}\text { Body } \\
\text { weight } \\
\text { index }\end{array}$} & \multicolumn{3}{|c|}{$\begin{array}{l}50 \text {-g oral GTT } \\
\text { glycaemia }(\mathrm{mmol} / \mathrm{l})^{b}\end{array}$} & \multirow[t]{2}{*}{$\begin{array}{l}\text { Patient } \\
\text { No. }\end{array}$} & \multirow[t]{2}{*}{ Sex } & \multirow[t]{2}{*}{ Age } & \multirow{2}{*}{$\begin{array}{l}\text { Body } \\
\text { weight } \\
\text { index }\end{array}$} & \multirow[t]{2}{*}{$\begin{array}{l}\text { Serum } \\
\text { biliru- }\end{array}$} & \multirow[t]{2}{*}{$\begin{array}{l}\text { Serum } \\
\text { albumin }\end{array}$} & \multirow[t]{2}{*}{ Ascites } & \multicolumn{3}{|c|}{$\begin{array}{l}50 \text {-g oral GTT } \\
\text { glycaemia }(\mathrm{mmol} / \mathrm{l})^{\mathrm{b}}\end{array}$} & \multirow{2}{*}{$\begin{array}{l}\text { Histo- } \\
\text { logical } \\
\text { examina- } \\
\text { tion }\end{array}$} & \multirow{2}{*}{$\begin{array}{l}\text { Aetiology } \\
\text { of cir- } \\
\text { rhosis }\end{array}$} \\
\hline & & & & 0 & $\begin{array}{l}60 \\
\min \end{array}$ & $\begin{array}{l}120 \\
\min \end{array}$ & & & & & & & & 0 & $\begin{array}{l}60 \\
\min \end{array}$ & $\begin{array}{l}120 \\
\min \end{array}$ & & \\
\hline 1 & $\mathrm{~F}$ & 47 & 1.12 & 4.44 & 9.77 & 5.99 & 1 & $\mathbf{M}$ & 60 & 0.83 & 23.9 & 25 & + & 4.61 & 8.10 & 4.05 & + & Alcoholic \\
\hline 2 & $\mathbf{M}$ & 55 & 0.90 & 5.00 & 7.10 & 5.99 & 2 & $\mathrm{~F}$ & 44 & 1.00 & 141.9 & 27 & + & 6.38 & 11.71 & 10.99 & + & Alcoholic \\
\hline 3 & $\mathbf{M}$ & 46 & 1.02 & 5.33 & 7.16 & 6.55 & 3 & $\mathbf{M}$ & 57 & 1.14 & 20.5 & 32 & Absent & 6.16 & 10.66 & 5.55 & + & Unknown \\
\hline 4 & $\mathbf{M}$ & 46 & 0.96 & 4.44 & 7.55 & 5.44 & 4 & $\mathrm{~F}$ & 45 & 0.88 & 111.1 & 24 & + & 5.00 & 7.55 & 3.55 & + & Alcoholic \\
\hline 5 & $\mathbf{M}$ & 51 & 1.05 & 5.33 & -5.94 & 4.33 & 5 & $\mathrm{M}$ & 55 & 0.94 & 65.0 & 22 & + & 4.94 & 8.60 & 6.38 & + & Alcoholic \\
\hline 6 & $\mathrm{M}$ & 48 & 0.97 & 4.44 & 8.55 & 6.05 & 6 & $\mathrm{~F}$ & 52 & 0.75 & 13.7 & 24 & Absent & 4.72 & 8.38 & 9.21 & + & Alcoholic \\
\hline 7 & $\mathrm{M}$ & 58 & 0.95 & 4.38 & 7.33 & 4.00 & 7 & $\mathbf{M}$ & 57 & 0.94 & 37.6 & 25 & + & 4.55 & 9.66 & 4.38 & + & Alcoholic \\
\hline 8 & $\mathbf{M}$ & 41 & 1.08 & 4.44 & 9.88 & 4.77 & 8 & $\mathrm{M}$ & 51 & 1.42 & 20.5 & 29 & + & 4.55 & 8.38 & 5.22 & + & Alcoholic \\
\hline 9 & $\mathrm{~F}$ & 49 & 0.94 & 4.38 & 6.55 & 4.77 & 9 & $\mathrm{~F}$ & 60 & 1.05 & 174.4 & 26 & Absent & 4.94 & 11.38 & 9.60 & + & Unknown \\
\hline 10 & $\mathbf{M}$ & 59 & 0.77 & 3.89 & 7.27 & 4.38 & 10 & M & 55 & 1.00 & 39.3 & 39 & + & 3.89 & 9.21 & 5.88 & + & Alcoholic \\
\hline 11 & $\mathbf{M}$ & 48 & 0.97 & 5.55 & 7.49 & 5.55 & 11 & $\mathrm{M}$ & 59 & 0.83 & 27.4 & 23 & + & 4.94 & 10.32 & 8.21 & $\begin{array}{l}\text { Not } \\
\text { studied }\end{array}$ & Unknown \\
\hline 12 & M & 32 & 0.96 & 4.77 & 7.10 & 5.00 & 12 & $\mathbf{M}$ & 32 & 0.97 & 23.9 & 44 & Absent & 4.94 & 7.27 & 5.94 & + & Unknown \\
\hline \multirow{2}{*}{\multicolumn{2}{|c|}{$\begin{array}{l}\text { Mean } \\
\pm S D:\end{array}$}} & 48.3 & 0.97 & 4.70 & 7.65 & 5.24 & & & 52.2 & 0.98 & & & & 4.97 & 9.27 & 6.58 & & \\
\hline & & \pm 6.8 & \pm 0.14 & \pm 0.50 & \pm 1.19 & \pm 0.81 & & & \pm 7.6 & \pm 0.17 & & & & \pm 0.68 & $\pm 1.19 \pm$ & $=2.38$ & & \\
\hline \multicolumn{7}{|c|}{$\mathrm{H}_{p}$ (versus healthy subjects) } & & & & & & & & 0.281 & 0.006 & 0.077 & & \\
\hline
\end{tabular}

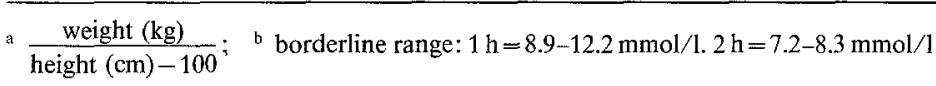

In 10 healthy subjects the result of the 50 -g oral GTT was normal, according to the criteria mentioned above and in two other cases the blood glucose level at $1 \mathrm{~h}$ was within the borderline range. A comparison of the mean blood glucose levels during this oral GTT showed a significantly higher value in the patients with cirrhosis at $1 \mathrm{~h}(9.27 \mathrm{ver}-$ sus $7.65 \mathrm{mmol} / 1, p=0.006$, Table 1 ).

For 3 days preceding the test the patients remained on a diet containing approximately $300 \mathrm{~g}$ carbohydrates $(70 \mathrm{~g}$ protein and $50-70 \mathrm{~g}$ fat); the test was performed always after a $12 \mathrm{~h}$ overnight fast. The investigation included determination of blood glucose and serum levels of total IRI, C-peptide and proinsulin in the fasting state and after a second oral glucose loading of $100 \mathrm{~g}$. The $100 \mathrm{~g}$ dose was chosen in order to be able to compare the results obtained with those reported in the literature.

Blood samples were taken from an antecubital vein via an indwelling catheter 30 and $5 \mathrm{~min}$ before and $15,30,45,60,75,90,120$ and $180 \mathrm{~min}$ after the intake of the test dose of glucose. The serum was centrifuged, frozen and stored at $-20^{\circ} \mathrm{C}$ until peptide determination. The blood glucose level was determined by the hexokinase method and peptides by radioimmunoassay, i.e. IRI by the double-antibody technique, using kits obtained from the Institute of Nuclear Research, Swierk, Poland. The detection limit (defined as the smallest quantity distinguishable from zero point $=250$ ) was $2.5 \mathrm{mU} / 1$ and the coefficient of variation $10 \%$. C-peptide was determined by Heding's method using M 1221 antibodies with a very high specificity [11], the detection limit was $0.01 \mathrm{nmol} / \mathrm{l}$ and the coefficient of variation $10 \%$. Proinsulin also was determined ad modum Heding: (1) binding of proinsulin, insulin and other IRI substances by sepharose-bound insulin antibodies; (2) binding by proinsulin of antibodies to C-peptide using $M 1229$ [12]. The detection limit was $0.002 \mathrm{nmol} / 1$ and the coefficient of variation $15 \%$.

The concentration of true insulin in the serum was calculated by subtraction of the proinsulin value from the IRI value (mU/1), based upon the finding that proinsulin has $66 \%$ of the immunological activity of insulin, i. e. that $0.01 \mathrm{nmol} / 1$ proinsulin reacts as $1 \mathrm{mU} / 1$ of IRI [13]. The results are presented as mean $\pm S D$, and the statistical significance of the differences in the compared groups was determined using Student's $\mathrm{t}$-test and regarding $p<0.05$ as the minimum significance value.

\section{Results}

\section{Blood Glucose Levels}

After a 100-g oral glucose load the difference in the mean blood glucose levels between the two groups was more pronounced (Table 2). In patients with cirrhosis the mean blood glucose level was significantly higher than in healthy subjects at nearly all time intervals. However, it did not reach values defined as typical of diabetes [20]. At $120 \mathrm{~min}$ the mean blood glucose level was $9.01 \pm 2.07 \mathrm{mmol} / 1$. In two patients only were higher values found $(11.1$ and $13.4 \mathrm{mmol} / 1)$.

\section{Serum Proinsulin Concentration}

In healthy subjects the serum proinsulin concentration rose gradually from $0.02 \mathrm{nmol} / 1$ to $0.25 \mathrm{nmol} / 1$, (> tenfold increase over basal values) between 90 and $120 \mathrm{~min}$ after glucose intake and remained significantly elevated up to $3 \mathrm{~h}$ (Table 2).

In patients with cirrhosis, the curve of the mean serum proinsulin had a similar shape, but higher levels were observed at all time intervals and, excepting at 60 and $75 \mathrm{~min}$, the difference from the control group was significant $(p=0.0039-0.001)$, and greatest at the end of the test.

\section{IRI and True Insulin Serum Concentrations}

The serum IRI concentration was significantly higher in the fasting patients with cirrhosis than in healthy subjects ( 0.091 versus $0.043 \mathrm{mU} / 1$, respectively, Table 2$)$. It 
Table 2. Blood glucose and serum concentrations of proinsulin, IRI, true insulin and C-peptide on fasting and after oral loading with $100 \mathrm{~g}$ glucose in healthy subjects and patients with cirrhosis

\begin{tabular}{|c|c|c|c|c|c|c|c|c|c|c|}
\hline & \multicolumn{10}{|l|}{ Time (min) } \\
\hline & -30 & -5 & +15 & +30 & +45 & 60 & 75 & 90 & 120 & 180 \\
\hline \multicolumn{11}{|l|}{$\begin{array}{l}\text { Blood glucose } \\
(\mathrm{mmol} / \mathrm{l})\end{array}$} \\
\hline $\begin{array}{l}\text { Healthy } \\
\text { subjects }(n=12)\end{array}$ & & $4.57 \pm 0.43$ & $6.79 \pm 1.23$ & $7.84 \pm 1.41$ & $8.60 \pm 1.50$ & $8.78 \pm 2.01$ & $\begin{array}{c}8.91 \pm 2.21 \\
(n=11)\end{array}$ & $7.96 \pm 2.49$ & $6.93 \pm 2.07$ & $5.37 \pm 1.62$ \\
\hline $\begin{array}{l}\text { Patients with } \\
\text { cirrhosis }(n=12)\end{array}$ & & $5.42 \pm 0.72$ & $7.94 \pm 1.14$ & $9.28 \pm 1.26$ & $10.08 \pm 1.64$ & $10.44 \pm 1.72$ & $10.48 \pm 2.24$ & $10.11 \pm 1.92$ & $9.01 \pm 2.07$ & $7.04 \pm 1.34$ \\
\hline$p$ & & 0.001 & 0.026 & 0.015 & 0.031 & 0.041 & 0.104 & 0.026 & 0.022 & 0.011 \\
\hline \multicolumn{11}{|l|}{$\begin{array}{l}\text { Serum proinsulin } \\
(\mathrm{nmol} / 1)\end{array}$} \\
\hline $\begin{array}{l}\text { Healthy } \\
\text { subjects }(n=12)\end{array}$ & $\begin{array}{c}0.020 \pm 0.012 \\
(n=8)\end{array}$ & $\begin{array}{c}0.017 \pm 0.008 \\
(n=9)\end{array}$ & $0.046 \pm 0.022$ & $0.083 \pm 0.036$ & $0.112 \pm 0.055$ & $0.148 \pm 0.073$ & $\begin{array}{c}0.185 \pm 0.100 \\
(n=11)\end{array}$ & $0.218 \pm 0.109$ & $0.250 \pm 0.117$ & $\begin{array}{c}0.161 \pm 0.063 \\
(n=11)\end{array}$ \\
\hline $\begin{array}{l}\text { Patients with } \\
\text { cirrhosis }(n=12)\end{array}$ & $\begin{array}{c}0.038 \pm 0.021 \\
(n=10)\end{array}$ & $\begin{array}{c}0.043 \pm 0.026 \\
(n=10)\end{array}$ & $0.075 \pm 0.032$ & $0.143 \pm 0.085$ & $0.187 \pm 0.091$ & $0.230 \pm 0.129$ & $0.288 \pm 0.143$ & $0.339 \pm 0.149$ & $0.383 \pm 0.163$ & $0.330 \pm 0.140$ \\
\hline$p$ & 0.039 & 0.009 & 0.019 & 0.035 & 0.022 & 0.068 & 0.060 & 0.033 & 0.031 & 0.001 \\
\hline \multicolumn{11}{|l|}{$\begin{array}{l}\text { Serum IRI } \\
(\mathrm{nmmol} / \mathrm{l})\end{array}$} \\
\hline $\begin{array}{l}\text { Healthy } \\
\text { subjects }(n=12)\end{array}$ & $0.043 \pm 0.025$ & $0.037 \pm 0.015$ & $0.238 \pm 0.086$ & $0.290 \pm 0.109$ & $0.335 \pm 0.137$ & $0.329 \pm 0.154$ & $\begin{array}{c}0.326 \pm 0.168 \\
(n=11)\end{array}$ & $0.351 \pm 0.153$ & $0.352 \pm 0.184$ & $\begin{array}{c}0.166 \pm 0.095 \\
(n=11)\end{array}$ \\
\hline $\begin{array}{l}\text { Patients with } \\
\text { cirrhosis }(n=12)\end{array}$ & $\begin{array}{c}0.091 \pm 0.026 \\
(n=8)\end{array}$ & $0.084 \pm 0.031$ & $0.283 \pm 0.108$ & $\begin{array}{c}0.482 \pm 0.336 \\
(n=11)\end{array}$ & $0.479 \pm 0.194$ & $0.567 \pm 0.293$ & $0.580 \pm 0.341$ & $0.673 \pm 0.355$ & $\begin{array}{c}0.679 \pm 0.403 \\
(n=11)\end{array}$ & $0.478 \pm 0.306$ \\
\hline$p$ & 0.0006 & 0.0008 & 0.265 & 0.074 & 0.048 & 0.020 & 0.036 & 0.008 & 0.018 & 0.003 \\
\hline \multicolumn{11}{|l|}{$\begin{array}{l}\text { Serum true insulin } \\
(\mathrm{nmol} / \mathrm{l})\end{array}$} \\
\hline $\begin{array}{l}\text { Healthy } \\
\text { subjects }(n=12)\end{array}$ & $\begin{array}{c}0.029 \pm 0.023 \\
(n=8)\end{array}$ & $\begin{array}{c}0.025 \pm 0.014 \\
(n=9)\end{array}$ & $0.209 \pm 0.105$ & $0.237 \pm 0.102$ & $0.266 \pm 0.120$ & $0.237 \pm 0.131$ & $\begin{array}{c}0.211 \pm 0.127 \\
(n=11)\end{array}$ & $0.216 \pm 0.109$ & $0.197 \pm 0.138$ & $\begin{array}{c}0.073 \pm 0.063 \\
(n=11)\end{array}$ \\
\hline $\begin{array}{l}\text { Patients with } \\
\text { cirrhosis }(n=12)\end{array}$ & $\begin{array}{c}0.068 \pm 0.024 \\
(n=8)\end{array}$ & $0.058 \pm 0.019$ & $0.237 \pm 0.105$ & $\begin{array}{c}0.386 \pm 0.325 \\
(n=11)\end{array}$ & $0.362 \pm 0.178$ & $0.422 \pm 0.262$ & $0.405 \pm 0.337$ & $0.462 \pm 0.341$ & $\begin{array}{c}0.448 \pm 0.422 \\
(n=11)\end{array}$ & $0.269 \pm 0.355$ \\
\hline$p$ & 0.004 & 0.0003 & 0.473 & 0.146 & 0.133 & 0.039 & 0.087 & 0.026 & 0.064 & 0.071 \\
\hline \multicolumn{11}{|l|}{$\begin{array}{l}\text { Serum C-peptide } \\
(\mathrm{nmol} / \mathrm{l})\end{array}$} \\
\hline $\begin{array}{l}\text { Healthy } \\
\text { subjects }(n=12)\end{array}$ & $0.45 \pm 0.21$ & $0.47 \pm 0.21$ & $1.33 \pm 0.49$ & $1.76 \pm 0.73$ & $2.31 \pm 0.76$ & $2.43 \pm 0.92$ & $2.57 \pm 0.98$ & $2.60 \pm 1.02$ & $2.48 \pm 0.95$ & $1.75 \pm 0.63$ \\
\hline $\begin{array}{l}\text { Patients with } \\
\text { cirrhosis }(n=12)\end{array}$ & $\begin{array}{c}1.01 \pm 0.82 \\
(n=11)\end{array}$ & $0.78 \pm 0.49$ & $1.40 \pm 0.70$ & $2.06 \pm 1.33$ & $2.39 \pm 1.41$ & $2.70 \pm 1.47$ & $2.99 \pm 1.65$ & $2.95 \pm 1.63$ & $3.35 \pm 2.02$ & $3.01 \pm 1.75$ \\
\hline$p$ & 0.033 & 0.053 & 0.760 & 0.498 & 0.857 & 0.594 & 0.469 & 0.537 & 0.190 & 0.035 \\
\hline
\end{tabular}

Results expressed as mean $\pm \mathrm{SD}$; number of subjects in parentheses

was significantly higher also after $100 \mathrm{~g}$ glucose from minute 45 of the test onwards; the significance of the difference increased the longer the duration of the test $(p=0.048-0.003)$. At $3 \mathrm{~h}$ the mean serum IRI level in the group of patients with cirrhosis was three times higher than in the control group.

After correction for the share of proinsulin in the IRI value, the calculated value of true insulin was also higher in the group of patients with cirrhosis than in healthy controls.

This difference was, however, not so pronounced as in the case of IRI and was statistically significant only in the fasting state and at 60 and $90 \mathrm{~min}$ after glucose intake. At $3 \mathrm{~h}$, when the difference between the serum IRI concentration reached the highest significance, the difference between true insulin values was not significant $(p=0.071)$.

\section{Serum C-Peptide Concentrations}

In healthy subjects the serum concentration of C-peptide after $100 \mathrm{~g}$ oral glucose load increased rapidly to a maximum value of $2.6 \mathrm{nmol} / 1$ at $90 \mathrm{~min}$, and from 120 min onwards it decreased (Table 2 ). In patients with cirrhosis, the course of the curve of the mean serum Cpeptide value was similar in shape and absolute values to that of healthy subjects. Only in the fasting state and at the end of the test were the mean serum C-peptide values significantly higher in patients with cirrhosis (1.01 versus $0.45 \mathrm{nmol} / 1 ; p=0.033$ ).

\section{Discussion}

The above results confirm the well known clinical observations that cirrhosis is a condition contributing to the development of disturbances in carbohydrate metabolism $[1,3,5,7,17]$. The results of the present investigations, giving a more accurate interpretation of the increased serum IRI concentration in the fasting state and after an oral glucose load, are of particular significance since they demonstrate that the higher values in patients with cirrhosis depend to some extent on the serum proinsulin concentrations, which are higher in both the 
fasting state and, particularly, in the later phase of an oral GTT. After calculation of true insulin it was found that the serum level of this hormone in patients with cirrhosis was also higher than in healthy subjects, but the difference was less significant than in the comparison of serum IRI concentrations.

In the fasting state the higher C-peptide and IRI concentrations are consistent with a hypersecretion of insulin. However, after glucose stimulation the lack of difference in serum C-peptide concentration between the cirrhotic group and the control group indicates that the true hyperinsulinaemia observed in patients with cirrhosis is not a result of hypersecretion of insulin (cf. $8,14)$. Direct determination of the IRI level in portal blood as reported by Greco et al. [10] could even suggest reduced insulin secretion in cirrhosis.

On the other hand, studies by Johnston et al. [15] carried out in patients with long-standing portal blockade and normal histological pattern of the liver, have demonstrated that excess insulin observed in the extrahepatic blood of these patients was not due to liver bypass by this hormone. A possible explanation of the peripheral hyperinsulinaemia in blood of patients with cirrhosis is the reduced uptake/degradation of this hormone by the liver. The unsolved question remains, however, whether the reduced insulin uptake is caused by decreased degradation of insulin due to the liver changes, or whether this is an active process of adaptation to maintain increased insulin supply to meet an increased demand of the peripheral tissues for this hormone.

The results presented in this study also confirm previous observations concerning high serum proinsulin level in the later phase of an oral GTT [13]. This confirmation means that in this phase of the test, the molar serum concentration of proinsulin prevails that of insulin. These observations, together with the detailed analyses of the blood levels of proinsulin, IRI, and true insulin presented here, suggest that many earlier views concerning blood insulin changes based on IRI determinations will have to be revised.

Acknowledgment. We wish to thank Mrs. Marianne Heiden for her skillful analytical assistance.

\section{References}

1. Berkowitz D (1969) Glucose tolerance, free fatty acids and serum insulin responses in patients with cirrhosis. Am J Dig Dis 14: 691-699

2. Block MB, Mako ME, Steiner DF, Rubenstein AH (1972) Circulating C-peptide immunoreactivity: studies in normals and diabetic patients. Diabetes 21: 1013-1026
3. Collins JR, Crofford OB (1969) Glucose intolerance and insulin resistance in patients with liver diseases. Arch Intern Med 124: 142-148

4. Creutzfeldt W, Frerichs H, Kraft W (1967) The intravenous tolbutamide test in liver disease. Acta Diabetol Lat 4: 209-230

5. Creutzfeldt W, Frerichs H, Sickinger K (1970) Liver diseases and diabetes mellitus. In: Popper H, Schaeffer E (eds) Progress in liver disease, vol 3, Grune \& Stratton, New York, pp 371-407

6. Czekalski S, Kozak W, Eder M, Gryczyńska M, Porawska J, Kozal $H(1977)$ The effect of glucagon on serum immunoreactive insulin concentration in patients with liver cirrhosis (in Polish). Pol Arch Med Wewn 58: 17-21

7. Felber JP, Megnenat P, Vanotti A (1967) Tolerance du glucose diminuée et résponse insulinique élevée dans la cirrhose. Schweiz. Med Wochenschr 97: 1537-1539

8. Gerö L, Korányi L, Szalay F, Büki B, Tamás jr. G (1982) Insulin, C-peptide and glucagon levels during OGTT in hepatic cirrhosis and in patients with prehepatic block. Acta Diabet Lat 11: $330-339$

9. Greco AV, Ghirlanda G, Patrone C, Fedeli G, Manna R (1974) Behaviour of pancreatic glucagon, insulin and $\mathrm{HGH}$ in liver cirrhosis after arginine and IV glucose. Acta Diabetol Lat 11:330-339

10. Greco AV, Circitti F, Ghirlanda G, Manna R, Altomonte L, Rebuzzi AG, Bertoli A (1979) Insulin and glucagon concentrations in portal and peripheral veins in patients with hepatic cirrhosis. Diabetologia 17: 23-28

11. Heding LG (1975) Radioimmunological determination of human C-peptide in serum. Diabetologia 11: 541-548

12. Heding LG (1977) Specific and direct radioimmunoassay for human proinsulin in serum. Diabetologia 13: 467-474

13. Heding LG, Kasperska-Czyźykowa T (1980) C-peptide and proinsulin after oral glucose. Acta Med Scand 639: 33-36

14. Johnston DG, Alberti KGMM, Faber OK, Binder C (1977) Hyperinsulinism of hepatic cirrhosis: diminished degradation or hypersecretion? Lancet 1: 10-12

15. Johnston DG, Alberti KGMM, Wright R, Smith-Laing G, Stewart AM, Sherlock S, Faber OK, Binder C (1978) C-peptide and insulin in liver disease. Diabetes 27:201-206

16. Kasperska T, Lawecki J, Rogala H, Czyżyk A (1971) The behaviour of insulinaemia in patients with liver cirrhosis after intravenous administration of glucose, tolbutamide and glucagon. Diabetologia 7: 391-394

17. Megyesi C, Samols E, Marks V (1967) Glucose tolerance and diabetes in chronic liver disease. Lancet 2: 1051-1055

18. Shurberg JL, Resnick RH, Koff RS, Ross E, Baum RA, Palotta JA (1977) Serum lipids, insulin and glucagon after portocaval shunt in cirrhosis. Gastroenterology 72:301-304

19. Smoczyński M (1975) Carbohydrate metabolism in liver cirrhosis. II. Insulinaemia after oral loading with glucose alone and in combination with glucagon and tolbutamide (in Polish). Pol Arch Med Wewn 54: 445-453

20. WHO Expert Committee on Diabetes Mellitus (1980) Second report. Technical Report Series 646. WHO, Geneva

Received: 22 March 1982

and in revised form: 20 July 1983

Dr. T. Kasperska-Czyźykowa

Department of Gastroenterology

and Metabolic Diseases

Medical Academy in Warsaw

ul. Lindleya 4

02-005 Warsaw, Poland 